\title{
From Inaction to External Whistleblowing: The Influence of the Ethical Culture of Organizations on Employee Responses to Observed Wrongdoing
}

\author{
Muel Kaptein
}

\begin{tabular}{|l|l|}
\hline \multicolumn{2}{|l|}{ ERIM REPORT SERIES RESEARCH IN MANAGEMENT } \\
\hline ERIM Report Series reference number & ERS-2009-047-ORG \\
\hline Publication & August 2009 \\
\hline Number of pages & 44 \\
\hline Persistent paper URL & http://hdl.handle.net/1765/16600 \\
\hline Email address corresponding author & Kaptein.Muel@kpmg.nl \\
\hline Address & Erasmus Research Institute of Management (ERIM) \\
& RSM Erasmus University / Erasmus School of Economics \\
& Erasmus Universiteit Rotterdam \\
& P.O.Box 1738 \\
& 3000 DR Rotterdam, The Netherlands \\
& Phone: + 31 10 408 1182 \\
& Fax: + 31 10 408 9640 \\
& Email: info@erim.eur.nl \\
& Internet: $\quad$ www.erim.eur.nl \\
\hline
\end{tabular}

Bibliographic data and classifications of all the ERIM reports are also available on the ERIM website: www.erim.eur.nl 


\section{ERASMUS RESEARCH INSTITUTE OF MANAGEMENT}

\section{REPORT SERIES}

\section{RESEARCH IN MANAGEMENT}

\begin{tabular}{|l|l|}
\hline \multicolumn{2}{|l|}{ ABSTRACT AND KEYWORDS } \\
\hline Abstract & $\begin{array}{l}\text { Putting measures in place to prevent wrongdoing in organizations is important, but de-tecting } \\
\text { and correcting wrongdoing is just as vital. Employees who observe wrongdoing should therefore } \\
\text { be encouraged to respond in a manner that supports corrective action. This paper examines the } \\
\text { influence of the ethical culture of organizations on employee responses to observed wrongdoing. } \\
\text { The findings show that, contrary to transparency and congruency of management, many other } \\
\text { dimensions of ethical culture were negatively related to inaction and external whistleblowing and } \\
\text { positively related to direct interven-tion, reporting to management and calling an ethics hotline. } \\
\text { The model used for ethical culture explained 27.5\% of intended responses by employees. }\end{array}$ \\
\hline Free Keywords & wrongdoing, ethical culture, reporting, ethics hotline, whistleblowing \\
\hline Availability & $\begin{array}{l}\text { The ERIM Report Series is distributed through the following platforms: } \\
\text { Academic Repository at Erasmus University (DEAR), DEAR ERIM Series Portal } \\
\text { Social Science Research Network (SSRN), SSRN ERIM Series Webpage } \\
\text { Research Papers in Economics (REPEC), REPEC ERIM Series Webpage }\end{array}$ \\
\hline Classifications & $\begin{array}{l}\text { The electronic versions of the papers in the ERIM report Series contain bibliographic metadata } \\
\text { by the following classification systems: } \\
\text { Library of Congress Classification, (LCC) } \underline{\text { LCC Webpage }} \\
\text { Journal of Economic Literature, (JEL), JEL Webpage } \\
\text { ACM Computing Classification System CCS Webpage } \\
\text { Inspec Classification scheme (ICS), ICS Webpage }\end{array}$ \\
\hline
\end{tabular}




\title{
FROM INACTION TO EXTERNAL WHISTLEBLOWING:
}

\section{THE INFLUENCE OF THE ETHICAL CULTURE OF ORGANIZATIONS ON EM- PLOYEE RESPONSES TO OBSERVED WRONGDOING}

\author{
Muel Kaptein \\ Department of Business-Society Management \\ RSM Erasmus University \\ Room T07-04 \\ P.O. Box 1738 \\ 3000 DR Rotterdam \\ The Netherlands \\ Tel.: +31 104082823 \\ E-mail: mkaptein@rsm.nl
}

Muel Kaptein, $\mathrm{PhD}$, is Professor of Business Ethics and Integrity Management at the Department of Business-Society Management at RSM Erasmus University. His research interests include the management of ethics, the ethics of management, and the measurement of ethics. He has published papers in Academy of Management Review, Business \& Society, Journal of Business Ethics, Journal of Management, Journal of Management Studies, Journal of Organizational Behavior, and Organization Studies. He is author of the books Ethics Management (Springer, 1998), The Balanced Company (Oxford University Press, 2002), The Six Principles of Managing with Integrity (Articulate Press, 2005), and The Living Code (Greenleaf, 2008). More information can be found on the website: www.muelkaptein@ com. 


\section{FROM INACTION TO EXTERNAL WHISTLEBLOWING:}

\section{THE INFLUENCE OF THE ETHICAL CULTURE OF ORGANIZATIONS ON EM-}

\section{PLOYEE RESPONSES TO OBSERVED WRONGDOING}

Putting measures in place to prevent wrongdoing in organizations is important, but detecting and correcting wrongdoing is just as vital. Employees who observe wrongdoing should therefore be encouraged to respond in a manner that supports corrective action. This paper examines the influence of the ethical culture of organizations on employee responses to observed wrongdoing. The findings show that, contrary to transparency and congruency of management, many other dimensions of ethical culture were negatively related to inaction and external whistleblowing and positively related to direct intervention, reporting to management and calling an ethics hotline. The model used for ethical culture explained $27.5 \%$ of intended responses by employees.

Keywords: wrongdoing, ethical culture, reporting, ethics hotline, whistleblowing 
Preventing wrongdoing in and by organizations is a significant responsibility and challenge for organizations, from a strategic (Schnatterly, 2003), financial (Karpoff, Lee, \& Martin, 2008), legal (Bamberger, 2006), societal (Tulder \& Van der Zwart, 2006), and ethical (Kaptein, 2008a) perspective. However, it is an illusion to believe that wrongdoing can be avoided entirely (Treviño \& Nelson, 1999). Even with the best preventative measures in place, wrongdoing still occurs. In keeping with the recommendations of the U.S. Federal Sentencing Guidelines for Organizations, it is therefore desirable that organizations detect and correct wrongdoing as it arises .

Employees are a "critical” (Miceli, Near \& Dworkin, 2008: 2), "increasingly important” (Miceli \& Near, 2005: 100) source for detecting wrongdoing (Miethe, 1999). Dyck, Morse and Zingales (2008), for example, show that $18.3 \%$ of the corporate fraud cases in large U.S. companies between 1996 and 2004 were detected and brought forward by employees. An analysis of 360 instances of fraud in organizations in Europe, the Middle East and Africa by KPMG (2007) shows that anonymous tipping by employees was the primary source of detection: $25 \%$ of the frauds were brought forward by employees. Failing to create the opportunity for internal reporting of wrongdoing "foolishly invites catastrophe" as Callahan (2002: 195) puts it. Therefore it is crucial that organizations encourage employees who suspect or observe wrongdoing not to look the other way or stick their head in the sand, but to respond in such a manner that the wrongdoing and wrongdoer(s) can be stopped and corrected (Miceli, Near, \& Dworkin, 2009). For this reason, the U.S. Federal Sentencing Guidelines and Sarbanes-Oxley Act (Section 806, 301 and 1107) encourage organizations to provide sufficient opportunity to employees for internal reporting of wrongdoing.

As Miceli, Near and Dworkin (2009) remark, employees who are aware of wrongdoing often refrain from reporting it. According to Mesmer-Magnus and Viswesvaran (2005), one reason for this is that organizations often do not welcome reports of wrongdoing. The question then is how organizations can create an environment that welcomes the disclosure of 
wrongdoing. According to Berry (2004), the ethical culture of organizations plays a crucial role in stimulating employees to report wrongdoing. In this paper we will examine how the different dimensions of ethical culture relate to different responses of employees to observed wrongdoing. The scientific contribution of this paper is threefold.

First, although many studies of the relationship between situational variables, such as national culture (Chiu, 2003; Patel, 2003; Tavakoli, Keenan, \& Crnjak-Karanovic, 2003), organizational structure (King, 1999), and type and seriousness of the wrongdoing (Near et al., 2004) and employees' response to observed wrongdoing have been conducted, the ethical culture of organizations as such has not been empirically examined. In this paper, the Corporate Ethical Virtues Model (Kaptein, 2008b), consisting of eight dimensions, will be used to assess the ethical culture of organizations. The model was developed to understand and explain unethical behavior by employees. In this paper, we will examine whether the model can also help us to understand the response of employees when they observe wrongdoing.

Second, whereas most research in the field focuses on internal and/or external whistleblowing (Lewis, 2001; Miceli et al., 2008; Miethe, 1999), this paper also examines reporting wrongdoing via the regular chain of command, that is, to management as well as resolving the wrongdoing by, for example, approaching the wrongdoer directly. Whether inaction can be explained by the ethical culture of organizations is also examined. An examination of the five different responses may improve our understanding of the way in which ethical culture and its dimensions are related to each response and the way in which the responses are related to each other. For organizations in particular it is relevant to know how different, complementary - as opposed to one or two individual - responses of employees contribute to detecting and correcting wrongdoing in the organization. Furthermore, it is relevant to include direct intervention and reporting via the regular chain of command, as these responses may well be more efficient, effective and ethical ways to respond to wrongdoing than internal or external whistleblowing. 
Third, whereas most studies use data obtained from students (Ayers \& Kaplan, 2005; Zhuang, Thomas \& Miller; 2005), a single sector, such as the federal government (Miceli, Rehg, Near, \& Ryan, 1999), or specific function, such as internal auditors (Miceli \& Near, 1994), nurses (King, 2001), or managers (Keenan, 2002), this paper uses a broad sample of the U.S. working population. Such a sample helps us to draw more generic conclusions about employee responses to observed wrongdoing. It also provides insight into the ethical culture of U.S. organizations at present and the responses it encourages among employees who observe wrongdoing.

\section{HYPOTHESES}

\section{Responses to observed wrongdoing}

Employees who observe wrongdoing are faced with the question "Do I stand up or do I stand by?” (Miceli \& Near, 2006), “Do I tell or do I not tell?” (Berry, 2004), or “Do I snitch or do I not snitch" (Pershing, 2003). When employees refrain from taking action, they become “inactive observers" (Miceli \& Near, 1992) or "silent observers" (Rothschild \& Miethe, 1999), which is undesirable when the norm is to prevent, detect and correct wrongdoing (Mi-

celi et al., 2008). ${ }^{1}$ When employees decide to take action, different options are available (cf., Elliston, 1982; Hirschman, 1970; Jubb, 1999; Miceli \& Near, 1984). The literature on whistleblowing draws a distinction between internal and external whistleblowing. Whistleblowing is mostly defined as "the disclosure by organization members (former or current) of illegal, immoral or illegitimate practices under the control of their employers, to persons or organizations that may be able to effect action" (Near \& Miceli, 1985: 4). Internal whistleblowing is usually defined as reporting wrongdoing outside the regular chain of command via, for exam- 
ple, confidential hotlines (Miceli et al., 2008). External whistleblowing can then be defined as reporting wrongdoing to someone outside the organization who may be able to stop or correct it. Most external whistleblowers first blow the whistle internally (Miceli et al., 2008; Rothschild \& Miethe, 1999) as the latter is less risky for the whistleblower (Miceli \& Near, 2002) and also less detrimental to the organization (Hassink et al., 2007). In contrast, external whistleblowing may lead to public embarrassment, government scrutiny, hefty fines, and litigation (Berry, 2004) as it not only exposes internal wrongdoing, but also a failing organization - one which is unable to stop and correct wrongdoing itself.

Although most research on employees' response to observed wrongdoing focuses on internal and external whistleblowing (cf., Miceli et al., 2008), other responses exist that tend to be preferred by ethicists (Bowie, 1982; DeGeorge, 1986; Velasquez, 2005) and organizations alike. These are often referred to in codes of conduct and whistleblowing policies (Hassink, de Vries, \& Bollen, 2007). Employees who observe wrongdoing can resolve the wrongdoing by approaching and confronting the wrongdoer(s) directly (Jubb, 1999). ${ }^{2}$ This gives the wrongdoer(s) the opportunity to take corrective action. It also gives the responding employees the opportunity to verify their interpretation of the alleged wrongdoing. For example, King (2001) found that nurses who observed unintentional wrongdoing preferred to approach the wrongdoer directly in order to give the wrongdoer the opportunity to explain and correct their conduct and to learn from the experience so as to avoid repeat behavior in future. Therefore, if employees successfully resolve the wrongdoing through direct intervention, unreported wrongdoing to management is, contrary to the view of Miceli et al. (2008), not necessarily negative. ${ }^{3}$ If the wrongdoer does not respond adequately, the observer can take the next step and report the wrongdoing to the supervisor in question, or when the wrongdoer is a supervisor, the manager in question. Should the supervisor or manager not respond appropriately, employees could report the wrongdoing to higher management until the report is handled satisfactorily. 
In this paper, we will study five types of responses of employees who observe wrongdoing: inaction, direct intervention, reporting to management, calling an internal ethics hotline, and external whistleblowing. On the one hand, the challenge for organizations is to encourage employees who detect wrongdoing to take action and to discourage inaction so that the wrongdoing and the wrongdoer can be corrected. On the other hand, the challenge is to ensure that employees take action internally rather than blow the whistle externally in order for the organization to draw on its self-correcting capacity so as to avoid external repercussions.

\section{Ethical culture}

Research shows that the motives of internal and external whistleblowers are not purely altruistic, but mixed. Dozier and Miceli (1985) describe these motives as prosocial in that whistleblowers weigh the costs and benefits of reporting wrongdoing to themselves and others (Miceli \& Near, 1985). Given that they consider the effectiveness of their actions, whistleblowers are not naïve (Near \& Miceli, 1995; Miceli \& Near, 2002). Dozier and Miceli (1985) are of the first scholars who have pointed to the relevance of situational stimuli that may encourage or discourage reporting wrongdoing. Empirical research even suggests that situational stimuli explain more variance in the decisions of whistleblower to act than individual variables do (Near \& Miceli, 1996). According to Miceli and Near (1984), it is therefore important that the stimuli situated in the organizational context enable the desired response. When the organizational context is unfavorable employees tend to report externally or not at all (Miceli and Near, 1992).

The ethical culture of an organization is one component of the organizational context. The ethical culture of an organization is usually defined as those elements of the perceived organizational context that impede unethical behavior and promote ethical behavior (Treviño 
and Weaver, 2003). Ethical culture represents part of the informal organizational context (Murphy, 1988), whereas policies, processes and programs represent part of the formal organizational context (Ferrell, Thorne LeClair, \& Ferrell, 1998). Sims and Keenan (1998) found that formal organizational policies that support external whistleblowing were not significant predictors of its occurrence, whereas informal elements were significant. ${ }^{4}$

Culture resides in the eyes of the beholder (cf., Schein, 2004; Weick, 1995) in that it involves perceptions, interpretations, experiences, and observations. It is held to be important because it is bound to influence the response of employees who observe wrongdoing. Five, partly overlapping reasons can be given for this. A first, normative, reason is that the culture of an organization embodies the values and norms of the organization. It indicates acceptable and unacceptable behavior that employees take into account when they decide how to respond. Miceli and Near (1984) note that employees rationalize inaction by attributing it to an organizational context perceived to be unreceptive to action. Employees are also less likely to act in a certain manner if they believe that the action would harm the existing organizational culture (Miceli \& Near, 1994). A second, power-related reason is that the stronger the shared culture, the greater the legitimacy employees feel to act in a manner that is consistent with the dominant culture (cf., Miceli \& Near, 1994). This sense of legitimacy imparts a degree of power to urge others to follow up reports of wrongdoing, as they and others know that responding to observed wrongdoing is consistent with the prevailing culture. A third reason concerns the expected consequences of actions. Expectancy theory holds that the expected consequences of an action influence the behavior of employees (Miceli \& Near, 1985). If employees, for example, believe that reports will be handled appropriately, they are more likely to take action than when they expect management to ignore reports. A fourth reason is related to the fact that the organizational culture is relevant not only to those who detect wrongdoing, but also to the recipients of reports of wrongdoing (Near \& Miceli, 1995). Employees will project their perception of the organizational culture on to that of the recipient and anticipate 
their actions accordingly. A fifth reason is that ethical culture influences the prevalence of wrongdoing in organizations. Attribution theory holds that individuals' perception of the causal mechanism underlying events influences their decision on how to respond to these events (Gundlach, Douglas, \& Martinko, 2003). When employees perceive the wrongdoing as an effect of a failing ethical culture, they are less likely to respond. Conversely, they are more likely to respond if they believe the wrongdoing to be an aberration and that the organization can and should learn from its shortcomings in order to prevent similar wrongdoing in future.

To date, the only existing model for the ethical culture of an organization is the Corporate Ethical Virtues Model, abbreviated as CEV Model, which will be used in this paper. Following Solomon's virtue-based theory of business organizations (1992, 1999), Kaptein (1998, 2008b) posits that the virtuousness of an organization can be determined by the extent to which the organizational culture promotes ethical and impedes unethical employee behavior. A corporate ethical virtue is a dimension of the ethical culture that promotes ethical behavior and impedes unethical behavior. To define desirable corporate ethical virtues, Kaptein (1998) conducted a qualitative analysis of 150 diverse cases of wrongdoing caused by a failing organizational culture. In another study, the resulting list of items was subjected to exploratory and confirmatory factor analyses resulting in eight dimensions of the ethical culture of organizations (Kaptein, 2008b). Below a hypothesis is developed on the relation between each dimension and each of the five possible responses of employees to observed wrongdoing in their organization: inaction, direct intervention, reporting to management, calling an ethics hotline, and external whistleblowing.

\section{The Cultural Dimension of Clarity}

The first cultural dimension is clarity, which is defined in the CEV Model as the extent to which the organization makes ethical expectations, such as values, norms and principles 
concrete and understandable to employees. Clarity concerns the manner in which employees are expected to conduct themselves in order to behave ethically towards stakeholders, the organization and each other. We expect that the more clarity there is, the more likely employees who observe wrongdoing are to take positive action, i.e. through direct intervention, reporting to management and calling an ethics hotline, and the less likely they are to refrain from taking action or blowing the whistle externally.

According to Near and Miceli (1985), the degree of clarity of the organizational context may determine how an employee responds to observed wrongdoing. Not only will more clarity increase the likelihood of an observer considering an act to be wrong, they are more likely to think that the wrongdoer knows or should have known that they are committing a transgression and that recipients of the report would also consider the act to be wrong. Clarity provides grounds on which to call the alleged wrongdoer to account and to denounce the wrongdoing. The more clarity there is, the more freedom, power and confidence an observer will have to bring the transgression to light (Near \& Miceli, 1987). The greater the clarity there is, the greater the responsibility employees will feel responsible to uphold it. Tolerating wrongdoing would suggest that the wrongdoing is "not that wrong" and create confusion, thus undermining clarity. Reporting wrongdoing in the hope that it will be corrected therefore contributes to preserving the current level of clarity. By reporting wrongdoing employees also evince their understanding of and commitment to the norm that is violated (Callahan, Dworkin, Fort, \& Schipani, 2002). The greater the level of clarity, the more employees will regard inaction as rendering them complicit (Jubb, 1999) since tolerating behavior that is considered to be wrong by the organization can encourage further wrongdoing. Greenberger et al. (1987) argue that employees are more likely to blow the whistle internally on behaviors that are unambiguously wrong and which colleagues disapprove of. For this reason, Callahan et al. (2002) posit that a code of conduct is the cornerstone of an organizational program to encourage internal whistleblowing. Miceli and Near (2002) also argue that organizations that wish to 
stimulate internal reporting should provide clear prescriptions on what constitutes wrongdoing.

The relationship between clarity and external whistleblowing is less clear. When an organization has no explicit standards to distinguish right form wrong, external reporting is less likely because it is more difficult to hold the organization accountable for conduct that has not been defined as wrong. At the same time, when the organization violates its own standards, it makes it easier to report externally because it provides evidence that the organization has violated a relevant norm: the organization cannot hide behind the specious argument that it was not aware of the existence or relevance of the norm. Violating one's own standards can be a reason to report, but external reporting is most likely in the event of transgressing a norm that is defined by society or stakeholders as legitimate and wrong to violate (Chung et al., 2004; Miceli et al., 1991). In such cases, it is not the clarity of organizational norms that is relevant, but the clarity of external norms. So we do not expect to find a relationship between clarity of organizational norms and external whistleblowing. To conclude, Hypothesis 1 reads as follows.

Hypothesis 1:Regarding the response of employees who observe wrongdoing, the cultural dimension of clarity is positively related to intervening directly, reporting to management, and calling an ethics hotline, negatively related to inaction, and unrelated to external whistleblowing.

The Cultural Dimension of Congruency of Local and Senior Management

A second and third dimension of the ethical culture of organizations is the congruency of local and senior management, which refers to the extent to which managers apply organizational standards to their own behavior. In this capacity, managers act as role models, which is 
important as it reinforces the importance of ethics and the clarity of standards. It is also important since employees are more likely to report upward if they trust their superiors (Near \& Miceli, 1985). Blackburn (1988) found that within a single organization, internal whistleblowers are more likely than inactive observers to believe that their managers cared about employees and could be counted on to do what they said. Near and Miceli (1996) found that internal whistleblowers report greater value congruence with management than inactive observers. This corresponds with the theory of value congruence as developed by Enz (1988) that holds that employees whose values correspond to that of management have relatively greater power in the organization than those whose values deviate. Furthermore, it is more likely that a transgression will be reported to a manager if the manager has not committed the same type of transgression in the past or is not implicated in the current observed transgression. We therefore expect a positive relation between congruency of management and reporting observed wrongdoing to management.

With regard to reporting observed wrongdoing to an ethics hotline, we expect a positive relationship with congruency of senior management and a negative relationship with local management. An ethics hotline is usually considered as a channel to report wrongdoing when local management is implicated in the wrongdoing or when previous reports of wrongdoing were handled unsatisfactorily. Employees who call an ethics hotline are in fact blowing the whistle on their immediate superiors (Elliston, 1982) as supervisors are often held responsible for the misdemeanors of their subordinates (Rothwell \& Baldwin, 2007). The greater the congruency of local management, the less likely employees are to contact the ethics hotline and the more likely they are to notify their supervisor or other local manager. At the same time, employees may perceive the ethics hotline as an extension of senior management as it often serves as means to report wrongdoing higher up in the organization. Callahan and Dworking (1994) note that the more senior the managers who are involved in the wrongdoing, the less useful a hierarchical reporting system is as it amounts to reporting wrongdoing to the wrong- 
doer, even if the system allows for anonymous reporting. For these reasons, congruency of senior management is expected to be positively related to the use of ethics hotlines.

Regarding external whistleblowing, we expect a negative relationship with both local and senior management. When managers are not viewed as role models and therefore less trustworthy, employees are more likely to report wrongdoing to an external organization or institution they trust, because employees will report to those persons or organizations they feel comfortable with. Also the more management is implicated in the wrongdoing, the less likely the report will be dealt with effectively and the more external reporting will be perceived as the only option to stop and correct the wrongdoing (cf., Miethe, 1999).

The relationship between congruency of management and resolving the wrongdoing directly is less easy to predict. On the one hand, the less congruent management is, the less employees will be able to rely on the intervention of management to stop the wrongdoing and the more they will be required to take action themselves. At the same time, the less congruent management is, the less supported and backed up by management employees will feel to resolve the wrongdoing themselves (Mesmer-Magnus \& Viswesvaran, 2005). Employees will not be able to count on management to correct wrongdoing when wrongdoers do not respond satisfactorily to employees' attempts to resolve the wrongdoing directly. Wrongdoers may also take this into account in deciding how to deal with colleagues who report wrongdoing to them. For example, it is easier for wrongdoers to disregard reports of colleagues when they know that when those colleagues decide to report to management, management will not take action. Possible threats or "scare tactics" (King, 2001: 10) of employees to report to management are less credible in those situations. On balance, we expect that congruency of management to be positively related to resolving the wrongdoing directly as the presence of role modeling has a greater impact than the absence of role modeling. As a consequence, we expect congruency of management to be unrelated to inaction because more congruence leads to more reporting to management, but also to less direct intervention by employees. 
Hypothesis 2: Regarding the response of employees who observe wrongdoing, the cultural dimension of congruency of local management is positively related to direct intervention and reporting to management, negatively related to calling an ethics hotline and external whistleblowing, and unrelated to inaction.

Hypothesis 3: Regarding the response of employees who observe wrongdoing, the cultural dimension of congruency of senior management is positively related to intervening directly, reporting to management and calling an ethics hotline, negatively related to external whistleblowing, and unrelated to inaction.

\section{The Cultural Dimension of Feasibility}

The next dimension of the ethical culture of organizations is feasibility, which refers to the extent to which the organization makes sufficient time, budgets, equipment, information and authority available to enable employees to fulfill their responsibilities. In the CEV Model, the dimension of feasibility is relevant because the more pressure employees are under to perform and meet targets and the fewer resources they have available, the higher the risk of wrongdoing. We do not expect to find any relationship between feasibility and the five types of responses of employees who observe wrongdoing. On the one hand, the lower the feasibility, the fewer resources employees have to report and the less likely they are to report. Reporting can, for example, be time-consuming for the observer as well as the recipient. When observers and possible recipients of reports are busy, there is less opportunity to meet each other and to discuss the wrongdoing. Low levels of feasibility may also stimulate employees to believe that stopping the wrongdoing is not a priority because meeting targets is more urgent. On the other hand, the lower the levels of feasibility, the more likely it is that employees will 
consider it to be the cause of the observed wrongdoing and the more reason they may have to report it in order for the wrongdoer and organization to learn from it. It is difficult to determine which of the two factors has a greater impact on the responses of employees. Therefore, we expect that these factors counterbalance each other and that the net effect of feasibility on the responses of employees who observe wrongdoing is negligent.

Hypothesis 4: Regarding the response of employees who observe wrongdoing, the cultural dimension of feasibility is unrelated to resolving wrongdoing directly, reporting to management, calling an ethics hotline, external whistleblowing and inaction.

\section{The Cultural Dimension of Supportability}

Another cultural dimension is supportability, which refers to the extent to which the organization stimulates identification with the ethics of the organization among employees. Tyler and Blader (2005), for example, found that when employees are encouraged to identify with the ethical values of their organization, they will be more intrinsically motivated to comply with the ethical standards of the organization. The more employees identify with the ethics of an organization, the more their sense of identity will be threatened or harmed by the transgressions of others (Nieuwenboer, 2008) and the more likely it is that they will take action to stop and correct the wrongdoing, whether through direct intervention, reporting to management or calling an ethics hotline. Miceli et al. (1991), for example, found that commitment to the organization correlated with the propensity of corporate auditors to report wrongdoing. Furthermore, if the wrongdoer is perceived to be committed to the ethics of the organization, employees are more inclined to interpret the wrongdoing as a mistake and to believe that the wrongdoer would be prepared to learn from it, making them more likely to approach the wrongdoer directly and resolve the wrongdoing. 
With regard to external whistleblowing, there is probably no relationship with the cultural dimension of supportability. Several empirical studies show that the greater majority of external whistleblowers consider themselves to be very loyal employees and therefore first blew the whistle internally. Only after the organization failed to respond adequately to internal reports did they blow the whistle externally (Miceli et al., 2008b). The dimension of supportability, however, concerns not the extent to which employees are loyal or committed to their organization, but the extent to which they support the ethics of the organization. However, we may expect that the more committed employees are to the organization, the more they also support the ethics of the organization, and vice versa. Like the dimension of clarity, supportability is related to internal organizational norms. External whistleblowing, however, is primarily related to identification with external norms. In that sense, we do not expect a relationship between external whistleblowing and the cultural dimension of supportability.

Hypothesis 5: Regarding the response of employees who observe wrongdoing, the cultural dimension of supportability is positively related to intervening directly, reporting to management and calling an ethics hotline, negatively related to inaction, and unrelated to external whistleblowing.

The Cultural Dimension of Transparency

Transparency is also a cultural dimension in the CEV Model, which refers to the degree to which wrongdoing and its consequences are visible to those who can act upon it internally - wrongdoers as well as colleagues, supervisors, managers, and subordinates. As internal reporting is a means of improving internal transparency (Miceli et al., 2008b), we expect that the more internal transparency there already is, the less likely it is that employees will report 
wrongdoing to the wrongdoer, management, and ethics hotline and the more likely it is that they will refrain from taking action or blowing the whistle externally.

Employees will report wrongdoing if they think that it will be effective; when it brings something to light that the recipient is unaware of. When employees think that management is already aware of the wrongdoing, they will have less or no reason to inform management. The same applies to the wrongdoer: when the observer believes that the wrongdoer is aware of their behavior and its effects, the observer will have less or no reason to approach the wrongdoer. And when employees think that others too, are aware of the wrongdoing - the more transparent the organization is, the more likely this is - and that is has already been reported (cf., Dozier \& Miceli, 1985), the less they will feel compelled to take action.

There are some mechanisms that might weaken the expected negative relationship between transparency and internal reporting. The higher the perceived transparency of the organization, the more observers will believe that others are aware of their observation of wrongdoing and therefore whether and how they responded to the observed wrongdoing. The more transparent the organization, and the more the organization encourages a positive response, the more employees will be stimulated to respond positively since their response is visible to others. Another mechanism is that the more transparent the organization is, the more visible the effects of wrongdoing are, thus the more convincing evidence observers have on the basis of which to report the wrongdoing, and the more likely it is that they will report (Miceli \& Near, 1985). A third mechanism is that the more transparent the organization is, the more employees will feel obliged to report wrongdoing so as to preserve existing levels of transparency.

Like inaction, we expect external whistleblowing to be positively related to transparency. External whistleblowing usually takes place only after employees have reported the wrongdoing internally (cf., Miceli \& Near, 1992). Only when management is aware of the wrongdoing but have not taken satisfactory action do employees have a legitimate reason to 
report externally (DeGeorge, 1986). So the greater the internal transparency of an organization, the greater the visibility and awareness of wrongdoing, thus the higher likelihood that employees will report externally.

Hypothesis 6: Regarding the response of employees who observe wrongdoing, the cultural dimension of transparency is positively related to inaction and external whistleblowing and negatively related to intervening directly, reporting to management, and calling an ethics hotline.

\section{The Cultural Dimension of Discussability}

The dimension of discussability in the CEV Model is defined as the extent to which ethical issues, such as ethical dilemmas and alleged wrongdoing, can be discussed internally. The process of reporting wrongdoing is a matter of communication (King, 1997). Reporting wrongdoing is to make things discussable; to break through communication barriers (Miceli et al., 2008b). In organizations with a low level of discussability, where a "code of silence" (Rothwell \& Baldwin, 2007) or an atmosphere prevails that is antagonistic to the exposure of wrongdoing (Miceli \& Near, 2002), employees will believe that dissidence and speaking up is undesirable (Miceli \& Near, 1984). In organizations with a low level of discussability, the messenger of wrongdoing will be retaliated against and the focus misdirected from resolving the wrongdoing to redressing, reprising and resenting the messenger (Keenan, 1990; Miceli \& Near, 1994). Dworkin and Baucus (1998) distinguish four types of retaliation against reporters of wrongdoing: nullification, isolation, defamation, and expulsion. Research conducted by Alford (2007), for example, describes how whistleblowers are regarded as "nuts and sluts" and treated as mentally disturbed or morally suspect. Retaliation could also mean that actions that would otherwise be taken are not taken, such as a promotion (Miceli et al., 2008b). If the 
possibility of retaliation exists, the willingness of employees to report wrongdoing will decline due to the costs they may have to bear as a result (Miceli et al., 2009). However, in organizations where dialogue and feedback are standard practice (Heard \& Miller, 2006), where there is empathy and an attempt to understand and listen (Sims \& Keenan, 1998), the willingness of employees to report wrongdoing internally is greater, because it preserves the prevailing norm of openness (Blackburn, 1988; Graham, 1993) and is appreciated by management and wrongdoers alike.

With regard to the use of an ethics hotline, we do not expect discussability to have any influence due to two opposing mechanisms that are at work. On the one hand, the higher the level of internal discussability within a department, the less likely it is that employees will use an ethics hotline because the hotline serves as safety net for alleged wrongdoing that cannot be addressed among employees within the department or through the regular chain of command (Kaptein, 2002). On the other hand, employees will not use a hotline if they believe that it will be met with disapproval or retaliation (cf., Miceli, 2004). Whereas Miceli (2004) is quite skeptical about ethics hotlines due to the fact that she doubts whether it has led to any change, Callahan et al. (2002) assert that the mere existence of a hotline has symbolic value in that it signals an openness to dissent within the organization.

Regarding external whistleblowing, we predict a negative relationship with discussability. The greater the level of internal discussability, the less likely employees are to report externally since they feel comfortable to address wrongdoing internally. To conclude, the next hypothesis reads as follows:

Hypothesis 7: Regarding the response of employees who observe wrongdoing, the cultural dimension of discussability is positively related to intervening directly and reporting to management, negatively related to inaction and external whistleblowing, and unrelated to calling an ethics hotline. 


\section{The Cultural Dimension of Sanctionability}

The final dimension in the CEV Model is sanctionability, which is defined as the extent to which employees believe that unethical behavior will be punished and ethical behavior will be rewarded, as well as the extent to which the organization learns from wrongdoing. When wrongdoing goes unpunished or is rewarded even, the implicit message is that wrongdoing is acceptable or even desirable. The dimension of sanctionability concerns the consequences not for employees who report wrongdoing, but for the wrongdoers. This dimension is especially relevant to employees who observe wrongdoing and proceed to assess the effectiveness of reporting it. According to Near and Miceli (1995), correction and termination of wrongdoing are important predictors of the behavior of potential whistleblowers. Miceli and Near (1984) found that convincing evidence that corrective action would be taken appeared to be important to nearly all potential whistleblowers. If reports are not taken seriously, employees will conclude that it is futile to report, which reduces the likelihood that they will report at all (cf., Miceli et al., 2008b). A high level of sanctionability, however, indicates that wrongdoing is not tolerated, which stimulates employees to take internal action. So we expect sanctionability to be positively related to direct intervention, reporting to management, and calling an ethics hotline. The higher the level of sanctionability, the less reason employees have to refrain from taking action internally and to report outside the organization. We therefore expect sanctionability to be negatively related to these two types of responses.

Hypothesis 8: Regarding the response of employees who observe wrongdoing, the cultural dimension of sanctionability is positively related to intervening directly, reporting to management, and calling an ethics hotline and negatively related to inaction and external whistleblowing. 


\section{METHOD}

Sample and Procedure

Data was collected from the U.S. working population. With the assistance of the panel database company, National Family Opinion, a representative sample was compiled of U.S. adults working for organizations that employ at least 200 people in fifteen selected industries. The privately registered, prescreened respondents to this blind survey received a nominal financial reward for their participation. The data collection took place between July and September 2008, yielding 5,065 completed questionnaires.

Of the respondents, $44 \%$ were female. With regard to job tenure, $6 \%$ had been working for less than a year at their current organization, $10 \%$ between 1 and 2 years, $16 \%$ between 3 and 5 years, $16 \%$ between 6 and 10 years, and $51 \%$ for more than 10 years. Of the respondents, $14 \%$ were aged $18-34,41 \%$ between 35 and 49 , and $45 \%$ were 50 or older. $28 \%$ of the respondents worked for an organization of 200 to 1,000 employees, $15 \%$ of 1,000 to 3,000 employees, $9 \%$ of 3,000 to 5,000 employees, $11 \%$ of 5,000 to 10,000 employees, and $38 \%$ of more than 10,000 employees. As for hierarchical level, $38 \%$ of the respondents held a managerial position, $13 \%$ worked as supervisor, $12 \%$ as mid-level manager, $3 \%$ as senior manager or junior executive, and $2 \%$ as senior executive or director. A wide range of sectors were represented: Consumer Markets (16\%), Government and Public Sector (14\%), Healthcare (9\%), Automotive (8\%), Aerospace/Defense (7\%), Electronics/Software (7\%), Banking and Finance (7\%), Pharmaceuticals (7\%), Media and Communications (6\%), Insurance (6\%), Chemicals and Diversified Industrials (5\%), Power and Utilities (4\%), Real Estate/Construction (2\%), Forestry/Mining (1\%), and Oil and Gas (1\%). The respondents had the following job functions: Manufacturing/Production (14\%), Operations/Service (13\%), 
Technology (10\%), Sales/Marketing (9\%), Research/Development/Engineering (9\%), General Management/Administration (7\%), Clerical/Support (7\%), Finance/Accounting (5\%), Quality/Safety/Environmental (4\%), Training/Education (3\%), Government/Regulatory Affairs (3\%), Purchasing/Procurement (2\%), Legal/Compliance (1\%), Internal Audit/Risk Management (1\%), Public/Media Relations (1\%), and other (11\%).

\section{Dependent variable}

As in studies conducted by Ayers and Kaplan (2005), King (2001), Tavakoli et al. (2003), and Victor et al. (1993), respondents were requested to indicate how they are inclined to respond to observed wrongdoing in their organization. Although intentions are not identical to behavior (cf., Mesmer-Magnus and Viswervaran, 2005; Miceli et al., 2008b), examining intentions has the advantage that the questions can be answered by all respondents, not only those who have observed wrongdoing in the past. It also helps us, which is especially useful to organizations, to predict responses instead of retrospectively study employee behavior. Moreover, the measurement of dependent and independent variables is better aligned - i.e. what employees currently think they would do if they observed wrongdoing is a better reflection of the current ethical culture in their organization. Assessing what respondents have done when they observed wrongdoing would imply that for a good measurement the culture has to be assessed for the same moment that respondents observed the wrongdoing, which would be difficult for respondents to reconstruct with risks of memory distortion and post-decisional justification (Miceli \& Near, 1988).

Wrongdoing was operationalized in a list of 37 items (Kaptein, 2008a) that respondents had to go through before answering questions related to the dependent variable. The five types of responses regarding observed wrongdoing, as described in this paper, were operationalized as "Try resolving the matter directly", "Notify my supervisor or another manager", 
"Call the ethics or compliance hotline", "Look the other way or do nothing" and "Notify someone outside the organization". For each reaction the Likert response scale ranged from "1 $=$ strongly disagree" to " $5=$ strongly agree", whereas the sixth response alternative was " $6=$ not applicable", which was treated as missing value in the analysis. So respondents were able to select multiple responses. For all certainty, a question was included to establish whether the respondents' organization had an ethics or compliance hotline. In the event that a respondent indicated that there was no hotline, the response to call an ethics hotline was recoded as "not applicable". To determine the explanatory value of the full model, a sixth variable, labeled as "total positive score", was created, which is the aggregate score for each respondent on intervening directly, reporting to management and calling an ethics hotline, minus inaction and external whistleblowing.

\section{Independent variables}

To measure the eight dimensions of the ethical culture of organizations, the questionnaire 'The Ethics and Integrity Thermometer' was used. ${ }^{5}$ Items were measured using a 5-point Likert scale ranging from " $1=$ strongly disagree" to " $5=$ strongly agree". The Cronbach's alphas of all dimensions, as depicted on the diagonal of Table 1, were above Nunally's (1978) suggested minimum of 0.70 .

\section{Control Variables}

Five control variables were first entered into the regression analyses: gender (two categories), age (eight categories), tenure (five categories), and hierarchical level (six categories) of respondents as well as the size of their organization (five categories). Miceli and Near (1988) found that whistleblowing was more likely among male observers: men have higher 
self-esteem, a stronger internal locus of control, and display more initiative. Younger employees are more likely to blow the whistle because their personal investment in the organization is lower than older employees (Near \& Miceli, 1985). However, highly ambitious younger employees seeking to advance their career in the organization, the so-called fast-trackers (Miceli \& Near, 1984), are less likely to blow the whistle (Near \& Miceli, 1985), especially when they have a short tenure (Joseph, 2003). Research by Miceli and Near (1988) demonstrates a positive relationship between tenure and whistleblowing. However, the meta-analysis of Mesmer-Magnus and Viswesvaran (2005) shows that tenure is only positively related to actual whistleblowing and not to the propensity to blow the whistle. Because this study also includes responses other than whistleblowing, tenure has for all certainty been included as control variable. Regarding the fourth control variable, the hierarchical level of the respondent, Keenan (2002) found that upper-level managers were more likely to blow the whistle on wrongdoing than middle-level and first-level managers. The reason for this is that upper-level

managers have greater discretionary powers and are under less pressure to conform and thus feel more comfortable to blow the whistle. The size of the organization may also be relevant. Near and Miceli (1985) argue that larger organizations are less dependent upon individual employees and are therefore more likely to retaliate, which has a negative impact on the likelihood of internal whistleblowing. At the same time, it is easier to remain anonymous in bigger organizations, which has a positive impact on the likelihood of whistleblowing.

\section{RESULTS}

Table 1 depicts the means, standard deviations, and intercorrelations of all research variables. The bivariate correlations between the dependent and independent variables ranged 
from $r=0.10(p<.01)$ for feasibility and resolving directly to $r=0.47(p<.01)$ for discussability and reporting to management as well as sanctionability and reporting to management.

\section{Insert Table 1 about here}

Table 2 depicts the results of the hierarchical regression analyses. Regarding inaction, one cultural dimension was positively related - transparency - and four dimensions were negatively related - clarity, supportability, discussability, and sanctionability. For intervening directly in observed wrongdoing, four dimensions were positively related - clarity, supportability, discussability, and sanctionability - whereas three dimensions were negatively related congruency of local management, congruency of senior management, and transparency. Reporting to management was positively related to five dimensions - clarity, congruency of local managers, supportability, discussability, and sanctionability - and negatively related to one dimension - transparency. Calling an ethics hotline was also positively related to five dimensions - clarity, congruency of senior management, feasibility, supportability, and sanctionability - and negatively related to one dimension - congruency of local management. External whistleblowing was positively related to one dimension - transparency - and negatively related to five dimensions - clarity, congruency of local management, congruency of senior management, discussability, and sanctionability. The final dependent variable, the total positive response, had four positive relationships - clarity, supportability, discussability, and sanctionability - and one negative relationship - transparency. 


\section{Insert Table 2 about here}

\section{DISCUSSION}

This study has examined the influence of the ethical culture of organizations on the potential response of employees to observed wrongdoing. We have examined the relationship between five types of responses and eight dimensions of ethical culture. A large sample of U.S. employees was used. The results of the study showed that three positive actions - intervening directly, reporting to management and calling an ethics hotline - were positively related to at least four of the eight dimensions of ethical culture. The two negative responses inaction and external whistleblowing - were negatively related to at least four of the eight dimensions of ethical culture. The model explained 27.5 of the variance of all responses combined.

The cultural dimensions of clarity, supportability and sanctionability were all positively related to the three positive actions. These three dimensions were also negatively related to inaction, and except for supportability, also to external whistleblowing. Congruency of local management was positively related only to reporting to management and negatively related to intervening directly, calling an ethics hotline and external whistleblowing. Congruency of senior management was positively related only to calling an ethics hotline and negatively related to intervening directly and external whistleblowing. Feasibility was unexpectedly positively related to calling an ethics hotline. As expected, transparency was negatively related to direct intervention and reporting to management, and positively related to inaction and external whistleblowing.

The findings of the study corroborate most of the hypotheses advanced in this study. Hypothesis 5 (supportability), 7 (discussability), and 8 (sanctionability) were fully supported. 
As for the other hypotheses, no or opposing evidence for one or two of their elements was found. Regarding Hypothesis 1, clarity was negatively related to external whistleblowing while we expected no relationship. One possible explanation for this finding is that as clarity increases, employees are more inclined to report internally, and consequently, less likely report externally. Clarity is indicative of the self-corrective capacity of an organization, and when a high level of clarity exists employees are bound to feel more comfortable to report internally. For Hypothesis 2 and 3 we found that both congruency of local and senior management are not positively, but negatively related to direct intervention. Contrary to expectations, role modeling of management appears to lead to more reporting to management and less direct intervention by employees. This might be because employees who regard their manager as good role models rely more on the intervention of their manager and consequently less on their own direct interventions to stop wrongdoing. They might regard the intervention of their manager as more effective or as a way to pass on the responsibility to their manager. It was also found that congruency of senior management was not related to reporting to management. As this paper presented arguments that suggest a positive relationship, this finding might be explained by some limitations in the methodology employed, which is discussed in the next section. Regarding Hypothesis 4, we found that feasibility was positively related to calling an ethics hotline, which is quite surprising and also, at least in view of the theories and arguments presented in this paper, difficult to explain. Regarding Hypothesis 6, we found that transparency was not related to calling an ethics hotline. Apparently, the presented arguments for reporting to management and approaching the wrongdoer(s) - the more transparency, the more they know about wrongdoing that takes place, and the less meaningful it is for employees to report to them, so that transparency is negatively related to these responses - is not applicable to calling an ethics hotline. A possible explanation for this is that since it is less easy for employees to know who the recipients of a report to an ethics hotline may be - an ethics hotline is more faceless - the more difficult it is to assess what the recipients already 
know. The current level of transparency of the organization could therefore be irrelevant to employees' decision to report or refrain from reporting to an ethics hotline. Future research could examine the explanation for this finding in greater detail.

The contribution of this paper lies in its demonstration of the relevance of the ethical culture of organizations in explaining and predicting employees' response to observed wrongdoing. The paper also demonstrates that the dimensions of ethical culture are not all positively related to a positive response and not all negatively related to a negative response of employees who observe wrongdoing. For example, transparency, which is a desirable organizational virtue for discouraging wrongdoing, was negatively related to the positive response of direct intervention and reporting to management, and positively related to the negative response of inaction and external whistleblowing. One cultural dimension, namely feasibility, was hardly related to any of the potential responses. Ray (2006) regards whistleblowing as an ethical failure at the organizational level. Based on the current study we can confirm that external whistleblowing generally reflects a weakness in the ethical culture of the organization, except for transparency. Transparency was positively related to external whistleblowing, whereas feasibility and supportability were not related to external whistleblowing. The relatively low explained variance $\left(\mathrm{R}^{2}\right)$ for external whistleblowing, as we will discuss in the next section, suggests that ethical culture is not the only relevant factor in explaining it. Considering inaction of employees as a failure of the ethical culture of organizations is generally also correct: only transparency was positively related. However, internal whistleblowing by calling an ethics hotline was positively related to five of the eight dimensions of ethical culture and negatively related only to congruency of local management. In contrast to the finding of Miceli and Near (1985), the present study suggests that inactive observers are confronted with a different organizational context than internal whistleblowers. Whereas Near and Miceli (1996) suggest that internal and external whistleblowing are related phenomena, we can confirm the finding of Dworkin and Baucus (1998) that we limit our understanding of the situational sti- 
muli for whistleblowing when we treat internal and external whistleblowing as one phenomenon. But we should also incorporate, which is another contribution of this study, inaction and resolving wrongdoing directly to improve our understanding of how employees respond to observed wrongdoing.

\section{Research Implications and Limitations}

Although the explanatory power of the model used for ethical culture was satisfactory for reporting to management and for all five responses combined - the adjusted $\mathrm{R}^{2}$ was .234 and .275 respectively - the explanatory power for external whistleblowing and direct intervention was low -.057 and .049 respectively. Low explained variances were also found in other studies of contextual stimuli for whistleblowing conducted by King (1997), Lee et al. (2004), Miceli and Near (2002), Rothwell and Baldwin (2007), and Victor et al. (1993). On the one hand, several other individual and situational factors could be added to better explain and predict employees' response to observed wrongdoing. In addition to the individual control variables of gender, tenure and age used in the present study, factors such as educational level (Near \& Miceli, 1995), religiosity and ethical ideology (Barnett, Bass, \& Brown, 1996) and ethical judgment (Chiu, 2003) have also been found to be relevant in explaining whistleblowing. Other relevant situational factors include role responsibility (Miceli, Dozier, \& Near, 1991), role prescription (Miceli \& Near, 2002), type and seriousness of wrongdoing (Near et al., 2004), intentionality of wrongdoer (King, 2001), cohesion among employees (Horne, 2001), national culture (Chiu, 2003; Patel, 2003; Tavakoli et al., 2003) and organizational structure (King, 1999). Not only would the inclusion of additional factors in future studies increase the explanatory power of the model, the operationalization of the factors in the present study could probably also be improved upon. 
Regarding the operationalization of the independent variables, this study has certain limitations, which have implications for future research. The objective of the study was to enhance our understanding of the influence of ethical culture on the response of employees who observe wrongdoing. A general model for the ethical culture of organizations was used to explain and predict wrongdoing. In future research, a complementary model could be developed for the ethical culture of organizations that is more focused on responses to observed wrongdoing. In such a model, the dimensions of the CEV Model could be worked out in more detail. With regard to clarity, for example, it could specify whether employees have clarity on how they should respond to wrongdoing; regarding congruency of managers, what role model behavior they display in response to wrongdoing observed; regarding supportability, the extent to which employees are committed to, for example, the whistleblowing policy of the organization; regarding feasibility, the availability of resources and different channels to report; regarding transparency, the extent to which employees are informed on how a report of wrongdoing is handled; regarding discussability, the extent to which receivers of reports of wrongdoing listen carefully and pose the right questions to get a good understanding of the reported wrongdoing; regarding sanctionability, whether reports of wrongdoing are appreciated. For a better understanding of the relationship between ethical culture and employee responses to observed wrongdoing, future research could also draw a distinction between the ethical culture of the immediate work environment of respondents and the broader organizational culture. In the current study we focused mainly on the ethical culture of the work unit. It is conceivable that in seeking an explanation for the responses that fall beyond the work unit, such as reporting to senior management and calling an ethics hotline, the broader context increases in significance. Likewise, it is conceivable that the ethical culture of the work unit increases in significance in the event that the wrongdoing and response, such as reporting to the supervisor, occurs within the work unit. 
Regarding the operationalization of the dependent variables, this study has certain limitations, which have implications for future research. This study focused on five types of responses of employees to observed wrongdoing. Future research could include a wider range of responses, such as reporting to different staff departments like HR, Legal, and Internal Audit, different levels of management, types of hotlines and different external persons and organizations. The exit option (Hirschman, 1970) could also be included as employees may respond to observed wrongdoing by transferring or leaving the organization. This study examined the propensity of employees to respond in a certain manner to observed wrongdoing, which should not be confused with what they actually do (cf., Mesmer-Magnus \& Viswervaran, 2005; Miceli et al., 2008b). Following Miceli and Near (2002), future research on the influence of ethical culture could also adopt a retrospective approach and examine the actual response of employees in the face of observed wrongdoing. In that case, the challenge will be to adequately deal with potential problems of memory distortion and post-decisional justification (Miceli \& Near, 1988) as discussed above.

Another limitation of the present study concerns the data that was used. Valid and reliable data is difficult to collect when studying a sensitive topic like responding to wrongdoing (Near \& Miceli, 1995). Although self-reported data may be flawed, it is widely used in studies on whistleblowing (cf., Miceli et al., 2008b) because it is important that data is collected anonymously, which cannot corroborated by a party other than the one that observes wrongdoing (Miceli \& Near, 1992). Given the cross-sectional data we used in this study, the cause and effect relationships cannot be established conclusively. For longitudinal research, employees would be required to identify themselves, which is likely to yield a low or biased response rate (Miceli \& Near, 1994). While this study focused on the influence of culture on employee responses to observed wrongdoing, the responses of employees may very well also influence the ethical culture. For example, reporting wrongdoing could strengthen the commitment of employees to the organization (Miceli et al., 2009). Reporting could also increase transparen- 
cy (Miceli et al., 2008a) and lead to sanctions (Miceli et al. 2008) thereby reinforcing or changing perceptions of the existing culture (cf., Miceli \& Near, 1985). Future research could also focus on how the response of recipients to reports of wrongdoing influence employee perceptions of the ethical culture of organizations. An interesting research question in this regard is how ethical culture relates to the number of actual reports. The quality of ethical culture is negatively related to the frequency of wrongdoing (Kaptein, 2009), but as the present study shows, a healthy ethical culture generally results in a greater willingness to report wrongdoing. The question is therefore what the net effect is. Regarding reports of workplace injuries and illness in the construction industry, Probst, Brubaker and Barsotti (2008) already found that organizations with a poor safety climate had significantly higher rates of underreporting to authorities but also more injuries and illness leading to a similar number of reports to authorities than organizations with a positive climate. An important question is what the influence of the cultural dimension of transparency is because transparency increases the likelihood that wrongdoing is observed. At the same time transparency decreases the likelihood that wrongdoing occurs and, as found in this study, the likelihood that wrongdoing is resolved directly or reported to management.

\section{Managerial Implications}

Given the importance of preventing, detecting and correcting wrongdoing, organizations should create a culture that encourages employees who observe wrongdoing to take appropriate action. Creating the infrastructure for internal whistleblowing via an ethics hotline or helpline is one way to encourage reporting. However, other studies tend to overlook responses like direct resolution of wrongdoing or reporting wrongdoing to a supervisor as a means to improve the self-correcting capacity of the organization. According to leading scholars in the field of whistleblowing, Miceli, Near and Dworkin (2008), most employees do not regard 
open door policies as effective and they have not been successfully employed to encourage internal reporting of wrongdoing. The current study shows that the majority, $81 \%$ of employees, has the propensity to report to their manager, $52 \%$ are oriented towards direct resolution, while $44 \%$ are inclined to call an ethics hotline. Adopting an integrated approach to the different routes available for reporting wrongdoing can contribute significantly to managing and enhancing the self-correcting capacity of the organization.

As illustrated in this study, the ethical culture of an organization is not only important in preventing wrongdoing, but also in encouraging employees to correct observed wrongdoing. Four dimensions are especially relevant in encouraging employees to take positive action such as intervening directly, reporting to management and calling an ethics hotline, instead of refraining to take action or blowing the whistle externally. These four dimensions are clarity, supportability, discussability and sanctionability. Encouraging a positive response to observed wrongdoing among employees requires developing a culture where standards for ethical behavior are clear, employees are committed to the ethics of organization, where ethical dilemmas and issues are open for discussion and where transgressors are punished. However, improving transparency may lead to a decline in wrongdoing, but also to a decline in the propensity to report wrongdoing internally. The same applies to role modeling of local management. Managers should realize that better role model behavior may lead to a lower propensity of employees to approach wrongdoers directly and to call the ethics hotline. To stimulate the right response, managers should be clear on how employees should respond when they observe wrongdoing. If a better ethical culture leads to less wrongdoing and a higher propensity to report to management, an interesting question for management is what the combined effect of these two factors is on the number of reports they receive. In this study we have found that more reports of wrongdoing is not necessarily negative. On the contrary, it could even be a positive reflection of the ethical culture of an organization. 


\section{REFERENCES}

Alford, C. F. (2007). Whistle-blowers narratives: the experience of choiceless choice. Social Research, 74, 223-48.

Ayers, S., \& Kaplan, S. E. (2005). Wrongdoing by consultants: An examination of employees' reporting intentions. Journal of Business Ethics, 57, 121-37.

Bamberger, K. A. (2006). Regulation as delegation: Private firms, decision-making, and accountability in the administrative state. Duke Law Journal, 56, 377-466.

Barnett, T., Bass, K., \& Brown, G. (1996). Religiosity, ethical ideology, and intentions to report a peer's wrongdoing. Journal of Business Ethics, 15, 1161-74.

Bergman, M., Langhout, R. D., Palmieri, P., Cortina, L.M., \& Fitzgerald, L. F. (2002). The (un)reasonableness of reporting: Antecedents and consequences of reporting sexual harassment. Journal of Applied Psychology, 87, 230-42.

Berry, B. (2004). Organizational culture: A framework and strategies for facilitating employee whistleblowing. Employee Responsibilities and Rights Journal, 16, 1-11.

Blackburn, M. S. (1988). Employee dissent: The choice of voice versus silence. Unpublished Doctoral Dissertation, The University of Tennessee, Knoxville.

Bowie, N. (1982). Business ethics. Englewood Cliffs, NJ: Prentice-Hall.

Callahan, E. S., \& Dworkin, T. M. (1994). Who blows the whistle to the media, and why: Organizational characteristics of media whistleblowers. American Business Law Journal, 32, 151-84.

Callahan, E. S., Dworkin, T. M., Fort, T. L., \& Schipani, C. A. (2002). Integrating trends in whistleblowing and corporate governance: promoting organizational effectiveness, societal responsibility, and employee empowerment. American Business Law Journal, 40, 177 215. 
Chiu, R. K. (2003). Ethical judgment and whistleblowing intention: Examination the moderating role of locus of control. Journal of Business Ethics, 43, 65-74.

Chung, J., Monroe, G. S., \& Thorne, L. (2004). An examination of factors affecting external and internal whistleblowing by auditors. Working paper, York University, Toronto.

DeGeorge, R. T. (1986). Business ethics. New York: MacMillan.

Dozier, J. B., \& Miceli, M. P. (1985). Potential predictors of whistle-blowing: A prosocial behavior perspective. Academy of Management Review, 10, 823-36.

Dworkin, T. M., \& Baucus M. S. (1998). Internal vs external whistleblowers: A comparison of whistleblowing processes. Journal of Business Ethics, 17, 1281-98.

Dyck, A., Morse, A., \& Zingales, L. (2008). Who blows the whistle on corporate fraud? Chigaco Booth. Working Paper 08-22.

Enz, C. (1988). The role of value congruity in intraorganizational power. Administrative Science Quarterly, 35, 504-29.

Elliston, F. A. (1982). Anonymity and whistleblowing. Journal of Business Ethics, 1, 167-77.

Ferrell, O. C., Thorne LeClair, D., \& Ferrell, L. (1998). 'The Federal Sentencing Guidelines for Organizations: A framework for ethical compliance. Journal of Business Ethic, 17, 353-63.

Graham, J. W. (1993). Blowing the whistle. Administrative Science Quarterly, 38, 683-85.

Greenberger, D.B., Miceli, M. P., \& Cohen, D. J. (1987). Oppositionists and group norms: the reciprocal influence of whistle-blowers and co-workers. Journal of Business Ethics, 6: $527-542$

Gundlach, M. J., Douglas, S.C., \& Martinko, M. J. (2003). The decision to blow the whistle: a social information processing framework. The Academy of Management Review, 28: 107123.

Hassink, H., de Vries, M., \& Bollen, L. (2007). A content analysis of whistleblowing policies of leading European companies. Journal of Business Ethics, 75, 25-44. 
Heard, E., \& Miller, W. (2006). Creating an open and non-retaliatory workplace. International Business Ethics Review, Summer, 1-7.

Hirschman, A. O. (1970). Exit, voice, and loyalty. Cambridge, MA: Harvard University Press.

Horne, C. (2001). The enforcement of norms: Group cohesion and meta-norms. Social Psychology Quarterly, 64, 253-66.

Joseph, J (2003). National Business Ethics Survey. Washington, D.C.: Ethics Resource Center.

Jubb, P.B. (1999). Whistleblowing: A restrictive definition and interpretation. Journal of Business Ethics, 21, 77-94.

Kaptein, M. (1998). Ethics management: Auditing and developing the ethical content of organizations. Dordrecht: Springer.

Kaptein, M. (2002). Guidelines for the development of an ethics safety net. Journal of Business Ethics, 41, 217-234.

Kaptein, M. (2008a). 'Development of a measure of unethical behavior in the workplace: A stakeholder perspective. Journal of Management, 34, 978-1008.

Kaptein, M. (2008b). Developing and testing a measure for the ethical culture of organizations: The corporate ethical virtues model. Journal of Organizational Behavior, 29, 92347.

Kaptein, M., \& Avelino, S. (2005). Measuring corporate integrity: A survey-based approach. Corporate Governance, 5, 45-54.

Kaptein, M., \& J. Dalen, van (2000). The empirical assessment of corporate ethics: A case study. Journal of Business Ethics, 24, 95-114.

Karpoff, J. M., Lee, D. S., \& Martin, G. S. (2008). The cost to firms of cooking the books, Journal of Financial and Quantitative Analysis, 43, 581-611. 
Keenan, J. P. (1990). Upper-level managers and whistleblowing: Determinants of perceptions of company encouragement and information about where to blow the whistle. Journal of Business and Psychology, 5, 223-35.

Keenan, J. P. (2002). Whistleblowing: A study of managerial differences. Employee Responsibilities and Rights Journal, 14, 17-32.

King, G. III (1997). The effects of interpersonal closeness and issue seriousness on blowing the whistle. The Journal of Business Communication, 34, 419-36.

King, G. III (1999). The implications of an organization's structure on whistleblowing. Journal of Business Ethics, 20, 315-26.

King, G. III (2001). Perceptions of intentional wrongdoing and peer reporting behavior among registered nurses. Journal of Business Ethics, 34, 1-13.

KPMG (2007). Profile of a fraudster survey 2007. Swiss: KPMG Forensic.

Lee, J.Y., Heilman, S.G., \& Near, J. P. (2004). Blowing the whistle on sexual harassment: Test of a model of predictors and outcomes. Human Relations, 57, 297-322.

Lewis, D. (2001). Whistleblowing at work: On what principles should legislation be based? The Industrial Law Journal, 30, 169-193.

Mesmer-Magnus J. R., \& Viswervaran, C. (2005). Whistleblowing in organizations: An examination of correlates of whistleblowing intentions, actions and retaliation. Journal of Business Ethics, 62, 277-97.

Miceli, M. P. (2004). Whistleblowing research and the insider: Lessons learned and yet to be learned. Journal of Management Inquiry, 13, 364-66.

Miceli, M. P., Dozier, J. B., \& Near, J. P. (1991). Blowing the whistle on data-fudging: a controlled field experiment. Journal of Applied Social Psychology, 76, 508-21.

Miceli, M. P., \& Near, J. P. (1984). The relationships among beliefs, organizational position, and whistleblowing status: A discriminant analysis. The Academy of Management Journal, 27, 687-705. 
Miceli, M. P., \& Near, J. P. (1985). Characteristics of organizational climate and perceived wrongdoing associated with whistleblowing decisions. Personnel Psychology, 38, 525-44.

Miceli, M. P., \& Near, J. P. (1988). Individual and situational correlates of whistleblowing. Personnel Psychology. 41, 267-81.

Miceli, M. P., \& Near, J. P. (1992). Blowing the whistle: The organizational and legal implications for companies and employees. New York: Lexington Books.

Miceli, M. P., \& Near, J. P. (1994). Relationships among value congruence, perceived victimization, and relation against whistle-blowers. Journal of Management, 20, 773-94.

Miceli, M. P., \& Near, J. P. (2002). What makes whistle-blowers effective? Three field studies. Human Relations, 55, 455-79.

Miceli, M. P., \& Near, J. P. (2005). Standing up or standing by: What predicts blowing the whistle on organizational wrongdoing. In J. Martocchio (Ed.). Research in personnel and human resources management (24, 95-136). Greenwich, CT: JAI/Elsevier Press.

Miceli, M.P. \& Near, J. P. (2006). Standing up or standing by: What predicts blowing the whistle on organizational wrongdoing? Research in Personnel and Human Resource Management, Joseph Martocchio, Editor.

Miceli, M. P., Near, J. P., \& Dworkin, T. M. (2008). Whistleblowing in organizations. New York: Routledge.

Miceli, M. P., Near, J. P., \& Dworkin, T. M. (2009). A word to the wise: How managers and policy-makers can encourage employees to report wrongdoing. Journal of Business Ethics, 86, 379-396.

Miceli, M. P., \& Near, J. P., \& Schwenk, C. P. (1991). Who blows the whistle and why? Industrial and Labor Relations Review, 45, 113-30.

Miceli, M. P., Rehg, M., Near, J. P., \& Ryan, K. (1999). Can laws protect whistle-blowers? Results of a naturally occurring field experiment. Work and Occupations, 26, 129-51. 
Miethe, T. D. (1999). Whistleblowing at work: Tough choices in exposing fraud, waste and abuse on the job. Boulder: Westview Press.

Miethe, T. D., \& Rothschild, J. (1994). Whistleblowing and the control of organizational misconduct. Sociological Inquiry, 64, 3, 322-47.

Murphy, P. E. (1988). Implementing business ethics. Journal of Business Ethics 7, 907-15.

Near, J. P., \& Miceli, M. P. (1985). Organizational dissidence: The case of whistleblowing. Journal of Business Ethics, 4, 1-16.

Near, J. P. \& Miceli, M. P. (1987). Whistle-blowers in organizations: Dissidents or reformers? Research in Organizational Behavior, 9, 321-68.

Near, J. P., \& Miceli, M. P. (1995). Effective whistleblowing. Academy of Management Review, 20, 679-708

Near, J. P., \& Miceli, M. P. (1996). Whistleblowing: Myth and reality. Journal of Management, 22, 507-26.

Near, J. P., Rehg, M. T., Scotter J. R. van, \& Miceli, M. (2004). Does type of wrongdoing affect the whistleblowing process? Business Ethics Quarterly, 14, 219-42.

Nieuwenboer, Den N. A. (2008). Seeing the shadow of the self: Studies on organizational deviance. Rotterdam: ERIM PhD-thesis.

Nunnally, J. C. (1978). Psychometric theory. New York: McGraw-Hill.

Patel, C (2003). Some cross-cultural evidence on whistleblowing as an internal control mechanism. Journal of International Accounting Research, 2, 69-97.

Pershing, J. L. (2003). To snitch or not to snitch? Applying the concept of neutralization techniques to the enforcement of occupational misconduct. Sociological Perspectives, 46, 149-78.

Probst, T. M., Brubaker, T. L., \& Barsotti, A. (2008). Organizational injury rate underreporting: the moderating effect of organizational safety climate. Journal of Applied Psychology, 93, 1147-54. 
Ray, S. L. (2006). Whistleblowing and organizational ethics. Nursing Ethics, 13, 438-45.

Rothschild, J. \& Miethe, T. D. (1999). Whistle-blower disclosures and management retaliation. Work and Occupations, 26, 107-28.

Rothwell, G. R., \& Baldwin, J. N. (2007): Ethical climate theory, whistleblowing, and the code of silence in police agencies in the State of Georgia. Journal of Business Ethics, 70, 341-61.

Schnatterly, K. (2003). Increasing firm value through detection and prevention of white-collar crime. Strategic Management Journal, 24, 587-614.

Schein, E. (2004). Organizational culture and leadership. San Francisco, CA.: Jossey Bass.

Sims, R. L., \& Keenan, J. P. (1998). Predictors of external whistleblowing: Organizational and intrapersonal variables. Journal of Business Ethics, 17, 411-21.

Solomon, R. C. (1992). Ethics and excellence. New York: Oxford University Press.

Solomon, R. C. (1999). A better way to think about business: How personal integrity leads to corporate success. New York: Oxford University Press.

Tavakoli, A. A., Keenan, J. P., \& Crnjak-Karanovic, B. (2003). Culture and whistleblowing: an empirical study of Croation and United States managers utilizing Hofstede's cultural dimensions. Journal of Business Ethics, 43, 49-64.

Treviño, L. K., \& Nelson, K.A. (1999), Managing business ethics. New York: John Wiley.

Treviño, L. K., \& Weaver, G. R. (2003). Managing ethics in business organizations: Social scientific perspectives. Stanford: Stanford University Press.

Tulder, R. van, \& Zwart, A. van der (2006). International business-society management. London: Routledge

Tyler, T. R., \& Blader, S. L. 2005. Can business effectively regulate employee conduct? The antecedents of rule following in work settings, Academy of Management Journal, 6, 114358 
Velasquez, M. G. (2005). Business ethics: Concepts and cases. Englewood Cliffs, N.J.: Prentice Hall.

Victor, B., Treviño L. K., \& Shapiro, D. L. (1993). Peer reporting of unethical behavior: the influence of justice evaluations and social context factors. Journal of Business Ethics, 12, $253-63$

Victor, B. \& Cullen, J. B. (1988). The organizational bases of ethical work climates. Administrative Science Quarterly, 33, 101-25.

Weick, K. (1995). Sensemaking in organizations. Thousand Oaks, CA: Sage Publications.

Zhuang, J., Stuart, T., \& Miller, D. L. (2005). Examining culture's effect on whistle-blowing and peer reporting. Business \& Society, 44: 462-86. 
Table 1

Means, Standard Deviations, (Pearson) Correlations and Scale Reliabilities for Dependent and Independent Variables

\begin{tabular}{|c|c|c|c|c|c|c|c|c|c|c|c|c|c|c|c|c|c|c|c|c|}
\hline Variables & $M$ & $S D$ & 1 & 2 & 3 & 4 & 5 & 6 & 7 & 8 & 9 & 10 & 11 & 12 & 13 & 14 & 15 & 16 & 17 & 18 \\
\hline 1. Inaction & 1.93 & .94 & & & & & & & & & & & & & & & & & & \\
\hline $\begin{array}{l}\text { 2. Direct inter- } \\
\text { vention }\end{array}$ & 3.35 & 1.11 & $-.070^{* * *}$ & & & & & & & & & & & & & & & & & \\
\hline $\begin{array}{l}\text { 3. Reporting } \\
\text { management }\end{array}$ & 4.00 & .85 & $-.411 * *$ & $.192 * *$ & & & & & & & & & & & & & & & & \\
\hline $\begin{array}{l}\text { 4. Calling ethics } \\
\text { hotline }\end{array}$ & 3.31 & 1.08 & $-.205^{* *}$ & $.047 * *$ & $.343 * *$ & & & & & & & & & & & & & & & \\
\hline $\begin{array}{l}\text { 5. External whis- } \\
\text { tleblowing }\end{array}$ & 2.21 & 1.02 & $.342^{* *}$ & .096 ** & $-.129 * *$ & $.122 * *$ & & & & & & & & & & & & & & \\
\hline $\begin{array}{l}\text { 6. Total positive } \\
\text { action }\end{array}$ & 6.18 & 2.80 & $-.681 * *$ & $.495^{* *}$ & $.694 * *$ & $.537 * *$ & $-.427 * *$ & & & & & & & & & & & & & \\
\hline 7. Gender & 1.56 & .50 & .020 & $.093 * *$ & $-.064 * *$ & $-.078 * *$ & -.002 & -.012 & & & & & & & & & & & & \\
\hline 8. Age & 46.47 & 9.09 & $-.103 * *$ & -.022 & $.028 *$ & $.034 *$ & $-.057 * *$ & $.066 * *$ & $.113 * *$ & & & & & & & & & & & \\
\hline 9. Tenure & 3.96 & 1.28 & -.013 & -.001 & -.028 & .013 & .003 & .009 & $.064 * *$ & $.311^{* * *}$ & & & & & & & & & & \\
\hline $\begin{array}{l}\text { 10. Hierarchical } \\
\text { level }\end{array}$ & 1.61 & 1.01 & $-.125^{* *}$ & $.220^{* *}$ & $.140 * *$ & $.065^{* *}$ & $-.058 * *$ & $.221 * *$ & $.096^{* *}$ & $.095^{* * *}$ & $.051 * *$ & & & & & & & & & \\
\hline 11. Size & 3.77 & 1.31 & $-.044^{* *}$ & -.022 & $.033^{*}$ & $.169^{* * *}$ & $-.038^{* * *}$ & $.113 * *$ & $.047 * *$ & .013 & $.124 * *$ & -.021 & & & & & & & & \\
\hline 12. Clarity & 4.10 & .79 & $-.270 * *$ & $.211 * *$ & $.356 * *$ & $.263 * *$ & $-.177 * *$ & $.441 * *$ & $-.035^{*}$ & $.059 * *$ & $.044 * *$ & $.183^{* * *}$ & $.097 * *$ & & & & & & & \\
\hline $\begin{array}{l}\text { 13. Congruency } \\
\text { local manage- } \\
\text { ment }\end{array}$ & 3.92 & .89 & $-.248 * *$ & $.147 * *$ & $.443 * *$ & $.221 * *$ & $-.225^{* *}$ & $.445^{* *}$ & $-.044 * *$ & .008 & $-.058 * *$ & $.133^{* * *}$ & $.056^{* * *}$ & $.540 * *$ & & & & & & \\
\hline $\begin{array}{l}\text { 14. Congruency } \\
\text { senior manage- } \\
\text { ment }\end{array}$ & 3.90 & .94 & $-.241 * *$ & $.123 * *$ & $.393 * *$ & $.276 * *$ & $-.226 * *$ & $.428 * *$ & $-.057 * *$ & .024 & $-.034 *$ & $.162 * *$ & .026 & $.570^{* * *}$ & $.676^{* * *}$ & & & & & \\
\hline 15. Feasibility & 3.47 & .58 & $-.153^{* *}$ & $.108 * *$ & $.294 * *$ & $.191^{* * *}$ & $-.113 * *$ & $.306 * *$ & $-.042 * *$ & -.021 & $-.054 * *$ & $.063^{* * *}$ & -.004 & $.348^{* * *}$ & $.501 * *$ & $.474 * *$ & & & & \\
\hline $\begin{array}{l}\text { 16. Supportabili- } \\
\text { ty }\end{array}$ & 3.91 & .82 & $-.271^{* *}$ & $.176^{* *}$ & $.392 * *$ & $.247 * *$ & $-.174 * *$ & $.438^{* *}$ & -.026 & $.046^{* *}$ & -.018 & $.152 * *$ & $.088^{* * *}$ & $.489^{* * *}$ & $.679^{* *}$ & $.548^{* *}$ & $.395^{* *}$ & & & \\
\hline 17. Transparency & 3.53 & .82 & $-.173 * *$ & $.129^{* *}$ & $.351^{* *}$ & $.232 * *$ & $-.128 * *$ & $.351 * *$ & $-.040^{* *}$ & -.004 & $-.049^{* *}$ & $.140 * *$ & .016 & $.428^{* * *}$ & $.630^{* * *}$ & $.562 * *$ & $.444^{* *}$ & $.650^{* * *}$ & & \\
\hline $\begin{array}{l}\text { 18. Discussabili- } \\
\text { ty }\end{array}$ & 3.74 & .80 & $-.264 * *$ & $.198^{* * *}$ & $.470 * *$ & $.240 * *$ & $-.210 * *$ & $.480^{* *}$ & -.021 & -.009 & $-.052 * *$ & $.148 * *$ & $.044^{* *}$ & $.514^{* * *}$ & $.787^{* * *}$ & $.650 * *$ & $.498 * *$ & $.716^{* * *}$ & $.675 * *$ & \\
\hline $\begin{array}{l}\text { 19. Sanctionabil- } \\
\text { ity }\end{array}$ & 3.68 & .84 & $-.274 * *$ & $.176 * *$ & $.470 * *$ & $.295 * *$ & $-.214 * *$ & $.495 * *$ & -.012 & -.011 & $-.057 * *$ & $.175^{* *}$ & $.058^{* * *}$ & $.530^{* * *}$ & $.776^{* * *}$ & $.711 * *$ & $.521 * *$ & $.696 * *$ & $.771 * *$ & $.799 * *$ \\
\hline
\end{tabular}

\footnotetext{
$* \mathrm{p}<.05 \quad * * \mathrm{p}<.01$
} 
Table 2

Results of Hierarchical Regression on Intended Responses of Employees to Observed Wrongdoing

\begin{tabular}{|c|c|c|c|c|c|c|}
\hline Variables & Inaction & $\begin{array}{l}\text { Directly } \\
\text { interven- } \\
\text { tion }\end{array}$ & $\begin{array}{c}\text { Reporting } \\
\text { to manage- } \\
\text { ment }\end{array}$ & $\begin{array}{l}\text { Calling } \\
\text { ethics hot- } \\
\text { line }\end{array}$ & $\begin{array}{c}\text { External } \\
\text { whistleb- } \\
\text { lowing }\end{array}$ & $\begin{array}{l}\text { Total posi- } \\
\text { tive action }\end{array}$ \\
\hline \multicolumn{7}{|l|}{ Control variables } \\
\hline Gender & .025 & $.089 * *$ & $-.053 * *$ & $-.069 * *$ & -.003 & -.015 \\
\hline Age & $-.092 * *$ & $-.060 * *$ & $.031 *$ & $.033^{*}$ & $-.049 * *$ & $.043 * *$ \\
\hline Tenure & .017 & .009 & -.018 & -.002 & .015 & -.005 \\
\hline Hierarchical level & $-.051 * *$ & $.172 * *$ & $.052 * *$ & -.003 & .007 & $.099 * *$ \\
\hline Size & -.007 & $-.057 * *$ & .000 & $.158 * *$ & -.016 & $.058 * *$ \\
\hline Clarity & $-.144 * *$ & $.165^{* *}$ & $.100 * *$ & $.117 * *$ & $-.043 *$ & $.204 * *$ \\
\hline Congruency local management & .025 & $-.055 *$ & $.074 * *$ & $-.114 * *$ & $-.085 * *$ & -.023 \\
\hline Congruency senior management & .001 & $-.082 * *$ & -.018 & $.101 * *$ & $-.100 * *$ & .031 \\
\hline Feasibility & .001 & .020 & .026 & $.051 *$ & .034 & .024 \\
\hline Supportability & $-.124 * *$ & $.060 * *$ & $.046^{*}$ & $.083 * *$ & .003 & $.125^{* *}$ \\
\hline Transparency & $.147 * *$ & $-.054 *$ & $-.068 * *$ & -.001 & $.113^{* *}$ & $-.132 * *$ \\
\hline Discussability & $-.066^{*}$ & $147 * *$ & $.183 * *$ & -.047 & $-.064 *$ & $.136 * *$ \\
\hline Sanctionability & $-.192 * *$ & $.077 *$ & $.222 * *$ & $.194 * *$ & $-.099 * *$ & $.257 * *$ \\
\hline Adjusted $R^{2}$ control variables & .026 & .058 & .027 & .044 & .006 & .056 \\
\hline Adjusted $R^{2}$ all variables & .126 & .107 & .261 & .144 & .063 & .331 \\
\hline $\begin{array}{l}\text { Adjusted } \Delta R^{2} \text { explanatory va- } \\
\text { riables }\end{array}$ & .100 & .049 & .234 & .100 & .057 & .275 \\
\hline$d f($ regression, residual) & $(13,4414)$ & $(14,4364)$ & $(13,4430)$ & $(13,4053)$ & $(13,4380)$ & $(13,3984)$ \\
\hline $\mathrm{F}$ & $50.231 * *$ & $38.480 * *$ & $121.971 * *$ & $53.569 * *$ & $23.816 * *$ & $152.912 * *$ \\
\hline
\end{tabular}
Note. Standardized regressions coefficients (betas) are shown. $* \mathrm{p}<.05 \quad * * \mathrm{p}<.01$ 


\section{Endnotes}

${ }^{1}$ In research conducted by Miceli et al. (2008b) whistleblowers are frequently distinguished from the group of employees who were unaware of wrongdoing. Non-observers fall beyond the scope of the current paper given that the focus is on the response of employees who observe wrongdoing.

${ }^{2}$ For example, in the study of Bergman et al. (2002) that examined the response of observers of sexual harassment, the response was limited to reporting, which was defined as the act of informing an organizational authority of the misdemeanor. The option of approaching the wrongdoer directly was therefore not included.

${ }^{3}$ For certain types of wrongdoing, such as legal transgressions, it might however be desirable that in addition to approaching the wrongdoer(s) directly, the observer report the wrongdoing to management because it is necessary that management sanction the wrongdoer, record the wrongdoing and take measures to correct the wrongdoing and prevent it from occurring again.

${ }^{4}$ Next to ethical culture, ethical climate is another component of the informal organizational context. Ethical climate is usually defined as the perception of employees about what constitutes unethical and ethical behavior in the organization (Victor \& Cullen, 1988). Some studies have been conducted on the relationship between ethical climate and whistleblowing. Rothwell and Baldwin (2007) did research among police agencies in the State of Georgia on ethical climates and whistleblowing. Chung et al. (2004) found that auditors are more likely to blow the whistle in a "principle-based" organizational climate compared to a "rule-based" organizational climate. Given the limited scope of the survey employed in the current study, questions regarding ethical climate were not included, which could be an interesting direction for future research.

${ }^{5}$ Version 2 of the Integrity Thermometer was used in this study. Version 1 is the questionnaire as developed and presented by Kaptein (1998) and Kaptein and Van Dalen (2000). Version 3 is the questionnaire as further developed and tested by Kaptein (2008b), which was not available at the time the data for the current study was collected. Version 2 (see, for example, Kaptein and Avelino (2005)) consists of 32 items. The difference between Version 1 and Version 2 is, for example, that Version 1 relates the dimensions of ethical culture to three key dilemmas organizations face (the dilemmas of the entangled hands, many hands and dirty hands) whereas Version 2 relates the dimensions of ethical culture to (un)ethical behavior in general. 


\section{Publications in the ERIM Report Series Research* in Management}

\section{ERIM Research Program: "Organizing for Performance"}

\section{9}

On the Specification of the Gravity Model of Trade: Zeros, Excess Zeros and Zero-Inflated Estimation

Martijn J. Burger, Frank G. van Oort, and Gert-Jan M. Linders

ERS-2009-003-ORG

http://hdl.handle.net/1765/14614

The Current State of Research on Networks in China's Business System

Johannes Meuer and Barbara Krug

ERS-2009-007-ORG

http://hdl.handle.net/1765/14842

Encountered Problems and Outcome Status in Nascent Entrepreneurship

A. Marco van Gelderen, B. Pankaj Patel, and A. Roy Thurik

ERS-2009-008-ORG

http://hdl.handle.net/1765/14913

The Ethics of Organizations: A Longitudinal Study of the U.S. Working Population

Muel Kaptein

ERS-2009-018-ORG

http://hdl.handle.net/1765/15405

From Symbolic to Substantive Documents: When Business Codes of Ethics Impact Unethical Behavior in the Workplace Muel Kaptein

ERS-2009-021-ORG

http://hdl.handle.net/1765/15909

Knowledge Management as a Strategic Tool to Foster Innovativeness of SMEs

Haibo Zhou, and Lorraine Uhlaner

ERS-2009-025-ORG

http://hdl.handle.net/1765/15913

Knowledge Management in the SME and its Relationship to Strategy, Family Orientation and Organization Learning Haibo Zhou, and Lorraine Uhlaner

ERS-2009-026-ORG

http://hdl.handle.net/1765/15914

Defining Respectful Leadership: What it is, how it can be measured, and another glimpse at what it is related to Niels van Quaquebeke, and Tilman Eckloff ERS-2009-027-ORG

http://hdl.handle.net/1765/15942

Blue Ocean versus Competitive Strategy: Theory and Evidence

Andrew Burke, André van Stel, and Roy Thurik

ERS-2009-030-ORG

http://hdl.handle.net/1765/16037

Pattern matching

Tony Hak and Jan Dul

ERS-2009-034-ORG

http://hdl.handle.net/1765/16203

Replication

Tony Hak and Jan Dul

ERS-2009-035-ORG

http://hdl.handle.net/1765/16204 
Theory-Building With Cases

Tony Hak and Jan Dul

ERS-2009-036-ORG

http://hdl.handle.net/1765/16205

Theory-Testing With Cases

Tony Hak and Jan Dul

ERS-2009-036-ORG

http://hdl.handle.net/1765/16206

Functional Polycentrism and Urban Network Development in the Greater South East UK: Evidence from Commuting Patterns, 1981-2001

B. de Goei, M.J. Burger, F.G van Oort, and M. Kitson

ERS-2009-038-ORG

http://hdl.handle.net/1765/16213

On the Economic Foundation of the Urban Network Paradigm: Spatial Integration, Functional Integration and Economic Complementarities within the Dutch Randstad

F.G. van Oort, M.J. Burger, and O. Raspe

ERS-2009-039-ORG

http://hdl.handle.net/1765/16214

Gender Pay Differences in the European Union: Do Higher Wages Make Up For Discrimination?

Erik Canton and Ingrid Verheul

ERS-2009-041-ORG

http://hdl.handle.net/1765/16215

What do We Know about Social Entrepreneurship: An Analysis of Empirical Research

Brigitte Hoogendoorn, Enrico Pennings, and Roy Thurik

ERS-2009-044-ORG

http://hdl.handle.net/1765/16558

Developing Innovative Competences in an Emerging Business System: New Private Enterprises in Hangzhou's Software Industry

Mark Greeven and Zhao Xiaodong

ERS-2009-045-ORG

http://hdl.handle.net/1765/16599

From Inaction to External Whistleblowing: The Influence of the Ethical Culture of Organizations on Employee Responses to Observed Wrongdoing

Muel Kaptein

ERS-2009-047-ORG

http://hdl.handle.net/1765/16600

* A complete overview of the ERIM Report Series Research in Management: https://ep.eur.nl/handle/1765/1

ERIM Research Programs:

LIS Business Processes, Logistics and Information Systems

ORG Organizing for Performance

MKT Marketing

F\&A Finance and Accounting

STR Strategy and Entrepreneurship 